\title{
Left ventricular hypertrophy are associated with increased ostial pulmonary vein diameter
}

Yoga Yuniadi, Radityo Prakoso, Erika Maharani, Budi Nagawijaya, Muhammad Munawar

\begin{abstract}
Abstrak
Fibrilasi atrium (FA) sering ditemui pada pasien hipertensi dengan hipertrofi ventrikel kiri (HVki). Vena pulmonalis (VP), yang berperan penting dalam terjadinya FA, mengalami peningkatan diameter ostialnya pada pasien FA. Tujuan penelitian ini untuk mengetahui perubahan vena pulmonalis pada HVki yang masih berirama sinus. Dari 70 subyek dengan hipertensi dan irama sinus, pada 42 subyek terdapat HVki. Ostium VP yang diukur memakai spiral multisliced CT scan, menunjukkan hasil berikut: kanan superior VP 19.6 \pm 2.78 vs $17.8 \pm 1.93(p=0.003)$, kanan inferior VP $18.4 \pm 3.12$ vs $16.0 \pm 2.19(p<0.001)$, kiri superior VP $18.1 \pm 2.62$ vs $16.0 \pm 2.16(p<0.001)$, dan kiri inferior VP $15.9 \pm 1.93$ vs $15.4 \pm 1.85 \mathrm{~mm}(p=0.284)$, pada pasien dengan dan tanpa HVki secara berturutan. Sekalipun dalam irama sinus, peningkatan diameter VP sudah terjadi pada HVki. Hasil ini mungkin dapat menerangkan tingginya prevalensi FA pada pasien dengan hipertensi. (Med J Indones 2006; 15:173-6)
\end{abstract}

\begin{abstract}
Atrial fibrillation (AF), which is called as a global epidemic disease, frequently found in hypertensive patients with left ventricular hypertrophy $(L V H)$. Pulmonary vein $(P V)$, which is known to have an important role in AF initiation and maintenance, increases in its diameter during AF. We sought to investigate PVs diameter changes in LVH with sinus rhythm. Of 70 hypertensive patients with sinus rhythm, 42 subjects demonstrated LVH. The mean ostial diameter of patient with and without LVH, assessed by doing spiral multisliced CT scan in the axial plane, were as follow: right superior (RSPV) of 19.6 $\pm 2.78 \mathrm{vs} 17.8 \pm 1.93(p=0.003)$, right inferior

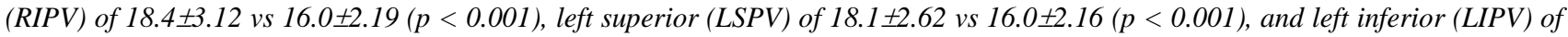
$15.9 \pm 1.93$ vs $15.4 \pm 1.85 \mathrm{~mm}(p=0.284)$, respectively. Even during sinus rhythm, LVH causes PV dilation. This result might give an explanation of frequent $A F$ prevalence in hypertensive patients. (Med J Indones 2006; 15:173-6)
\end{abstract}

Keywords: Pulmonary veins, Left ventricular hypertrophy

The huge incidence of atrial fibrillation (AF) in the world has been notified as a global epidemic disease. Pulmonary veins (PVs) were found to be important sources of ectopic beats for the initiation and maintenance of paroxysmal AF. ${ }^{1}$ Recent publication showed the special electrophysiology characteristics of PV including an isolation of special conducting cell in the PV that augment the likelihood of AF origin. ${ }^{2,3}$

Clinical data showed that AF is associated with hypertension especially if left ventricle hypertrophy (LVH) is present. ${ }^{4}$ The mechanism of hypertension induce $\mathrm{AF}$ still controversial. But, the dilation of $\mathrm{PV}$ has been found in $\mathrm{AF}$ patients and thought to be $\mathrm{AF}$

Department of Cardiology and Vascular Medicine, Faculty of Medicine, University of Indonesia/National Cardiovascular Center Harapan Kita, Jakarta, Indonesia risk factor. ${ }^{5}$ In addition, previous report revealed that diameter of arrhythmogenic PVs was significantly larger compared to non arrhythmogenic PVs. ${ }^{6}$ Since the PV anatomy in hypertensive patients with sinus rhythm has not been widely elucidated, we sought to elaborate the PV anatomy changes in hypertensive patients with evidence of left ventricle hypertrophy.

\section{METHODS}

\section{Patients Selection}

This is a case control study comparing the PVs ostial diameter of hypertensive patients with and without left ventricle hypertrophy using multislice CT scan. The study group consisted of 42 hypertensive patients with the evidence of $\mathrm{LVH}$, and the control group consisted of sex matched 28 hypertensive patients without LVH. 


\section{CT Imaging}

All subjects were underwent multi-sliced chest CT scan with $0.75 \mathrm{~mm}$ collimation and rapid administration of intravenous contrast media. The identification and measurement technique of PV has been noted elsewhere. ${ }^{7}$ In brief, the CT dataset was transferred to threedimensional (3-D) workstation, where 3-D reconstruction of left atrium (LA) was performed to define the PV anatomy, ostial diameter, and its orientation at the junction of LA (Figure 1). Because PVs frequently do not make a $90^{\circ}$ angle with the atrium but rather have funnel-shaped distal segments, the ostial diameter were measured at the point of the smallest angle with the atrial wall. Measurement of PVs was taken at the largest diameter on the axial plane (Figure 2). LVH is defined by thickening of interventricular septum wall more than $12 \mathrm{~mm}$, and is determined by measuring axial plane of left ventricle (LV) by CT scan at the level of papillary muscle. ${ }^{8}$ (Figure 3 ) All measurements were performed by the single radiographer who was blinded to the patient history.

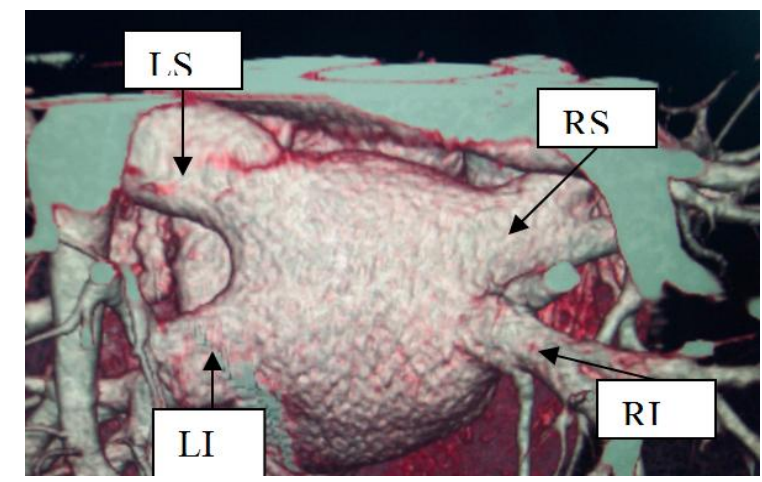

Figure 1. Three dimensional LA-PV reconstruction. The figure shows posterior view of $L A-P V$ junction. $L S=$ left superior $P V$, $L I=$ left inferior $P V, R S=$ right superior $P V, R I=$ right inferior $P V$.

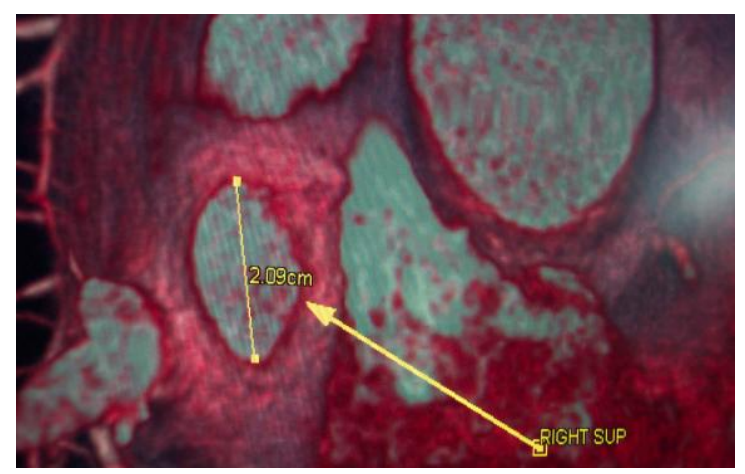

Figure 2. Measurement of ostial diameter. The figure shows largest ostial diameter measurement of right superior pulmonary vein. The measured diameter is $20.9 \mathrm{~mm}$

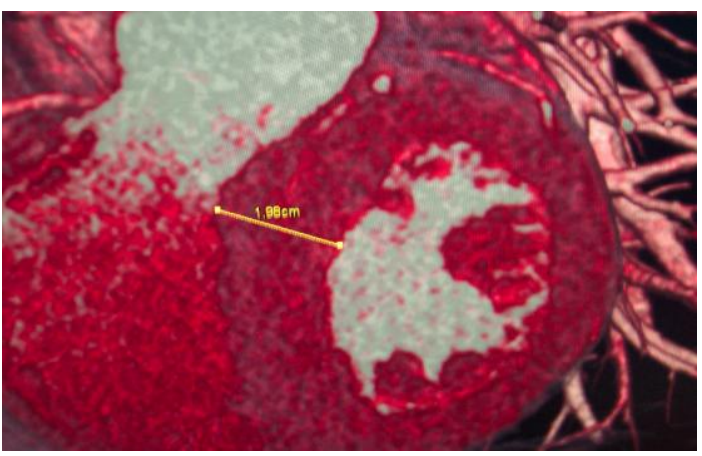

Figure 3. LVH identification. The interventricle septum was measured from axial plane at the level of papillary muscle. Here, the measured thickness was $19.0 \mathrm{~mm}$

\section{Statistical Analysis}

Continues variables are expressed as mean \pm 1 SD. Independent t-test was used to analyze difference of PVs diameter between patients with and without LVH. A p value $<0.05$ was considered statistically significant. All statistical analysis was performed using the SPSS 13.0 software.

\section{RESULTS}

\section{Clinical Characteristics}

Of 70 subjects eligible for this study comprised of 48 male. In the majority of patients, hypertension was controlled by calcium channel blocker (CCB) (13\%). The rests were taken angiotensin converting enzyme (ACE) inhibitor (9\%) and angiotensin II receptor blocker (ARB) (3\%) or other antihypertensive drug in anytime during their medication period. The mean values of blood pressure were $131 \pm 12.5 / 82 \pm 10.3$ and $134 \pm 29.1 / 82 \pm 11.3 \mathrm{mmHg}$ in $\mathrm{LVH}$ and non-LVH group respectively. The mean interventricular septum thickness in subjects with $\mathrm{LVH}$ was $15.1 \pm 0.23 \mathrm{~mm}$ as compare to $10.2 \pm 0.18 \mathrm{~mm}$ in non-LVH group ( $\mathrm{p}<0.001)$. (Table 1) Sixteen percent of patients had coronary artery disease, $2 \%$ had diabetes mellitus, and $2 \%$ had arrhythmias.

Table 1. Clinical Characteristics

\begin{tabular}{lcc}
\hline Characteristics & LVH & Non-LVH \\
\hline Age & $58 \pm 8.1$ & $53 \pm 10.3$ \\
IVS & $15.1 \pm 2.34$ & $10.2 \pm 1.81$ \\
SBP & $131 \pm 12.5$ & $133 \pm 29.1$ \\
DBP & $82 \pm 10.3$ & $82 \pm 11.3$ \\
\hline
\end{tabular}

$\mathrm{LVH}=$ left ventricle hypertrophy, age in year, IVS = interventricular septum thickness at the level of papillary muscle (in $\mathrm{mm}$ ), $\mathrm{SBP}=$ systolic blood pressure, $\mathrm{DBP}=$ diastolic blood pressure 


\section{Ostial Diameter}

We measured 280 PVs from 70 subjects. All subjects had 4 PVs which were divided into right inferior PV (RIPV), right superior PV (RSPV), left inferior PV (LIPV), and left superior PV (LSPV). The mean ostial diameters of patient with and without $\mathrm{LVH}$ were as follow: RSPV of $19.6 \pm 2.78$ vs $17.8 \pm 1.93$ ( $\mathrm{p}=0.003$ ), RIPV of $18.4 \pm 3.12$ vs $16.0 \pm 2.19$ (p < 0.001), LSPV of $18.1 \pm 2.62$ vs $16.0 \pm 2.16(\mathrm{p}<0.001)$, and LIPV of $15.9 \pm 1.93$ vs $15.4 \pm 1.85 \mathrm{~mm}(\mathrm{p}=0.284)$, respectively. (Table 2) More than 60 percent of subject demonstrated oblong ostial morphology and the rests were circular.

Table 2. Ostial Diameter

\begin{tabular}{lccc}
\hline Pulmonary Veins & $\begin{array}{c}\text { LVH } \\
(\mathrm{mm})\end{array}$ & $\begin{array}{c}\text { Non-LVH } \\
(\mathrm{mm})\end{array}$ & p value \\
\hline Right Superior & $19.6 \pm 2.78$ & $17.8 \pm 1.93$ & 0.003 \\
Right Inferior & $18.4 \pm 3.12$ & $16.0 \pm 2.18$ & $<0.001$ \\
Left Superior & $18.1 \pm 2.62$ & $16.0 \pm 2.16$ & $<0.001$ \\
Left Inferior & $15.9 \pm 1.93$ & $15.4 \pm 1.84$ & 0.284 \\
\hline
\end{tabular}

The largest PV ostial diameter measured from axial plane (in millimeter). $\mathrm{LVH}=$ left ventricle hypertrophy, $\mathrm{p}$ value $<0.05$ was considered statistically significant.

\section{DISCUSSION}

This study demonstrated that patients with LVH are having larger PVs diameter compare to that without LVH. The increase of PVs diameter has been occurred even the cardiac rhythm still normal sinus rhythm.

Currently, either PV angiography, CT scan or magnetic resonance imaging (MRI) have been used to demonstrate the anatomy of LA and PVs. Using MRI, Kato et $\mathrm{al}^{9}$ showed that the PV ostia were more oblong than circular which give us reason to choose the largest diameter measurement in this study. The dilation of $\mathrm{PVs}$ in AF patients have been reported ${ }^{5}$ but its mechanisms is unclear. Herweg et $\mathrm{al}^{10}$ found that $\mathrm{AF}$ patients with hypertension and/or LVH had greater PVs diameter compare to that without hypertension and/or LVH. Our finding showed that the PVs dilation already happen in sinus rhythm patient with LVH. This new discovery gives away the possibility mechanism of AF in hypertensive patients. Since the prevalence of diastolic dysfunction is found approximately in $75-85 \%$ of mild to moderate hypertension and reached of $90 \%$ in LVH patients, ${ }^{11}$ our finding supports the mechanism of diastolic dysfunction as the cause of PVs dilation.

Ostial PVs - LA junction areas demonstrate special histological structure. Nathan et $\mathrm{al}^{12}$ are first to describe the presence of muscular sleeves continuing from LA into the PV with a mean extent of $13 \mathrm{~mm}$. The longest sleeves were over the superior vein, and it was correlated with the relative distribution of PV ectopy described by Haissaguerre. ${ }^{1}$ The meshlike arrangement of myocytes bundle in the sleeves appeared to be relevant to the role of the PVs in the initiation of $\mathrm{AF} .{ }^{9}$ Compare to the control, patients with prior history of AF demonstrated shorter effective and functional refractory periods (ERP and FRP). Interestingly, the LA ERP of both patients group were similar, hence there was ERP gradient between LA and PV which was shorter in PVs of AF patients but longer in PVs of control patients. ${ }^{13}$ The consistent finding of PVs dilation in AF along with its electrophysiological changes seem to be an interdependency process which have important role in AF occurrence. Mechano-electrical feedback due to stretch might impacts on the triggering substrate and on the atrial myocardial remodeling processes leading to perpetuation of AF. In animal models, acutely elevated atrial pressure increases the rate and organization of wavelets emanating from the PVs. ${ }^{11}$

The interesting results of our finding that the mean diameter of all PVs in Indonesian population are larger compare to that of western people ${ }^{14}$ (RIPV of $17.2 \pm 2.93$ vs $15.7 \pm 2.8 \mathrm{~mm}$, RSPV $18.7 \pm 2.54$ vs $16.3 \pm 3.8 \mathrm{~mm}$, LIPV of $15.6 \pm 1.89$ vs $15.8 \pm 1.3 \mathrm{~mm}$ and LSPV of $17.1 \pm 2.61 \mathrm{vs} 14.8 \pm 3.5 \mathrm{~mm}$ for Indonesia and western people respectively). It is of important value in electrophysiological field, especially in era of $\mathrm{PV}$ isolation for $\mathrm{AF}$ management. This basic information will guide the electrophysiologist or physician in choosing or designing appropriate electrode catheter for PV isolation. Unfortunately we couldn't perform statistical analysis to determine the significance of differences between those data.

The superior PVs diameter showed more significant enlargement compare to that of inferior PVs. These finding were relevant to the previous study. Tsao et $\mathrm{al}^{5}$ measured the PVs diameter of AF patients by mean of MRI and found that the superior PVs to be larger when this was corrected for concomitant increase in LA size. The more complex myocardial sleeves arrangement in superior PV has been thought 
to be important for initiation and maintenance of AF. The mechanism of relation between complex myocardial arrangements of superior PVs and its larger diameter are unclear, but seminal work of Haissaguerre showed that the superior PVs are predominantly arrhythmogenic. ${ }^{1}$ Furthermore Yamane et $\mathrm{al}^{6}$ reported that diameters of arrhythmogenic PVs were significantly larger than those of nonarrhythmogenic.

Limitation: Lack of medication matching between $\mathrm{LVH}$ and non-LVH group in current study might have influence to diastolic dysfunction. ACE inhibitor and $\mathrm{CCB}$ have been proven to regress LVH. The regression of $\mathrm{LVH}$ by $\mathrm{ARB}$ results in improvement of LA dimension and function ${ }^{15}$ which in turn might be influence the PVs diameter.

\section{CONCLUSION}

PVs diameter enlarge in LVH patient with sinus rhythm. This finding might be one explanation of high prevalence rate of AF in hypertensive patients.

\section{Acknowledgment}

The investigators were acknowledging Mr. Irfan, the technician who gave great assistance in operating multi-sliced CT data base.

\section{REFERENCES}

1. Haissaguerre M, Jais P, Shah DC, Takahashi A, Hocini M, Quiniou G, Garrigue S, Le Mouroux A, Le Metayer P, Clementy J. Spontaneous initiation of atrial fibrillation by ectopic beats originating in the pulmonary veins. $\mathrm{N}$ Engl $\mathbf{J}$ Med. 1998; 339: 659-66

2. Chen YJ, Chen SA. Electrophysiology of pulmonary veins. J Cardiovasc Electrophysiol. 2006; 17: 220 - 4

3. Perez-Lugones A, McMahon JT, Ratliff NB, Saliba WI, Schweikert RA, Marrouche NF, et al. Evidence of specialized conduction cells in human pulmonary veins of patients with atrial fibrillation. J Cardiovasc Electrophysiol. 2003; 14: 803 - 9

4. Fuster V, Ryden LE, Asinger RW, Cannom DS, Crijns HJ, Frye RL, et al. ACC/AHA/ESC guidelines for the management of patients with atrial fibrillation: executive summary. J Am Coll Cardiol. 2001; 38: 1231 - 65

5. Tsao HM, Yu WC, Cheng HC, Wu MH, Tai CT, Lin WS, et al. Pulmonary vein dilation in patients with atrial fibrillation: Detection by magnetic resonance imaging. J Cardiovasc Electrophysiol. 2001; 12: 809 - 813

6. Yamane T, Shah DC, Jais P, et al. Dilatation as a marker of pulmonary veins initiating atrial fibrillation. J Interv Card Electrophysiol. 2002; 6: 245 - 9

7. Schwartzman D, Lacomis J, Wigginton WG. Characterization of left atrium and distal pulmonary vein morphology using multidimensional computed tomography. J Am Coll Cardiol. 2003; 41: 1349 - 57

8. Bruzzi JF, Rémy-Jardin M, Delhaye D, Teisseire A, Khalil C, Rémy J. When, why, and how to examine the heart during thoracic CT: Part 1, Basic Principles. Am J Roentgenol. 2006; 186: 324 - 32

9. Kato R, Lickfett L, Meininger G, et al. Pulmonary vein anatomy in patients undergoing catheter ablation of atrial fibrillation: Lessons learned by use of magnetic resonance imaging. Circulation. 2003; 107: $2004-10$

10. Herweg B, Sichrovsky T, Polosajian L, Rozenshtein A, Steinberg JS. Hypertension and hypertensive heart disease are associated with increased ostial pulmonary vein diameter. J Cardiovasc Electrophysiol. 2005; 16: 2 - 5

11. Kalifa J, Jalife J, Zaitsev AV, Bagwe S, Warren M, Moreno $\mathrm{J}$, et al. Intra-atrial pressure increases rate and organization of waves emanating from the superior pulmonary veins during atrial fibrillation. Circulation. 2003; 108: $668-71$

12. Nathan H, Eliakim M. The junction between the left atrium and the pulmonary veins. An anatomic study of human hearts. Circulation. 1966; 34: $412-22$

13. Jais P, Hocini M, Macle L, et al. Distinctive electrophysiological properties of pulmonary veins in patients with atrial fibrillation. Circulation. 2002; 106: $2479-85$

14. Cirillo S, Tosetti I, Gaita F, Bianchi F, Gandini G, Regge D. Magnetic resonance angiography of the pulmonary veins before and after radiofrequency ablation for atrial fibrillation. Radiol Med. 2005; 109: 488 - 99

15. Mattioli AV, Bonatti S, Monopoli D, Zennaro M, Mattioli G. Influence of regression of left ventricular hypertrophy on left atrial size and function in patients with moderate hypertension. Blood Press. 2005; 14: $273-8$ 